Jurnal Perikanan (2019) Volume 9. No. 2 : 130-136

DOI : https://doi.org/10.29303/jp.v9i2.156

\title{
PENGARUH KONSENTRASI PUPUK UREA TERHADAP PERTUMBUHAN POPULASI ROTIFER (Brachiounus plicatilis)
}

\author{
The Effect of The Concentration of Urea Fertilizer On Rotifer (Brachionus plicatilis) \\ Population Growth \\ Nurlinda ${ }^{1}$, Saptono Waspodo ${ }^{1}$, Sadikin Amir ${ }^{1}$ \\ ${ }^{1)}$ Program Studi Budidaya Perairan, Fakultas Pertanian, Universitas Mataram
}

\begin{abstract}
Abstrak
Penelitian ini bertujuan untuk mengetahui pengaruh kosentrasi pupuk urea terbaik terhadap pertumbuhan populasi rofiter (Brachionus plicatilis). Metode yang digunakan dalam penelitian ini yaitu metode eksperimen menggunakan Rancangan Acak Lengkap (RAL), dengan 4 perlakuan yaitu pemberian KW21 1ml/L sebagai kontrol, urea $50 \mathrm{mg} / \mathrm{L}$, urea 100 $\mathrm{mg} / \mathrm{L}, 150 \mathrm{mg} / \mathrm{L}$ yang di ulang sebanyak 3 kali. Pengamatan kepadatan dilakukan selama 24 jam. Parameter yang diamati meliputi laju pertumbuhan populasi, pertumbuhan relatif, pertumbuhan spesifik dan waktu penggandaan diri. Hasil penelitian menunjukan bahwa laju pertumbuhan populasi rotiter tertinggi 4.34 ind $/ \mathrm{mL}$ yang di capai pada hari ke-6 (fase eksponensial), pertumbuhan relatif tertinggi $76.33 \%$, pertumbuhan spesifik tertinggi $1.88 \%$, serta waktu penggandaan diri tersingkat 1.31 per jam. Berdasarkan penelitian ini, untuk pertumbuhan dianjurkan menggunakan kosentrasi pupuk urea dengan dosis $150 \mathrm{mg} / \mathrm{L}$.
\end{abstract}

Kata kunci : Urea, Rotifer (Brachionus plicatilis), pertumbuhan

\begin{abstract}
This study aims to determine the effect of the best concentration of urea fertilizer on population growth of rofiter (Brachionus plicatilis). The method used in this study is an experimental method using a Completely Randomized Design (CRD), with 4 treatments namely giving KW21 1ml / L as a control, urea $50 \mathrm{mg} / \mathrm{L}, 100 \mathrm{mg} / \mathrm{L}$ urea, $150 \mathrm{mg} / \mathrm{L}$ which is repeated as many as 3 time. Observation of density was carried out for 24 hours. Parameters observed include population growth rate, relative growth, specific growth and self-doubling time. The results showed that the highest rotiter population growth rate was 4.34 ind / mL achieved on the 6th day (exponential phase), the highest relative growth of $76.33 \%$, the highest specific growth of $1.88 \%$, and the shortest self-doubling time of 1.31 per hour. Based on this study, for growth it is recommended to use urea fertilizer at a dose of $150 \mathrm{mg} / \mathrm{L}$.
\end{abstract}

Keywords: Urea, Rotifer (Brachionus plicatilis), growth

\section{Pendahuluan}

Potensi budidaya perikanan laut berkembang sangat pesat akan tetapi belum diimbangi dengan ketersediaan larva yang berkualitas, baik dari segi jumlah, mutu dan keberlangsungannya. Faktor yang mempengaruhi kegiatan pembenihan adalah penyediaan pakan larva yang cukup dan tersedia pada waktu yang bersamaan saat pembudidaya menggunakan pakan buatan, namun keberadaan pakan alami sangat mutlak dibutuhkan dan tak tergantikan (Sururi, 2014). Pakan alami terutama plankton memegang peranan penting dalam penyediaan sumber protein dan nutrisi bagi larva, salah satunya yaitu pakan alami jenis Rotifera.

Rotifera merupakan salah satu spesies zooplankton yang sering digunakan

*korespondensi : nurlinda95@gmail.com 
sebagai pakan awal larva ikan laut, udang dan kepiting. Rotifera sering digunakan pada kegiatan pembenihan ikan laut karena jenis pakan tersebut memiliki keuntungan dibanding zooplankton lainnya (Redjeki, 1999). Rotifera mempunyai keunggulankeunggulan sebagai berikut: mudah dicerna oleh larva ikan, mempunyai ukuran yang sesuai dengan mulut larva ikan, mempunyai gerakan yang sangat lambat sehingga mudah ditangkap oleh larva, mudah dikultur secara massal, pertumbuhan dan perkembangannya sangat cepat dilihat dari siklus hidupnya, tidak menghasilkan racun atau zat lain yang dapat membahayakan kehidupan larva serta memilki nilai gizi yang paling baik untuk pertumbuhan larva (Redjeki, 1999). Namun demikian pembudidaya fitoplankton selalu menggunakan pupuk komersial yaitu KW21 yang merupakan produk import dari Jepang, dan cukup diandalkan untuk kultur mikroalga skala laboratorium, akan tetapi harga pupuk KW21 yang mahal dan susah didapatkan sehingga menjadi pertimbangan. Maka dari itu solusi alternatif mengganti pupuk KW21 ke pupuk yang lain dilakukan agar menekan biaya pengeluaran pelaku budidaya.

Solusi pemecah masalah ini adalah pemanfaatan pupuk pertanian yang relatif murah dan mudah diperolah. Dalam bidang pertanian, pupuk digunakan sebagai sumber unsur hara yaitu pupuk Urea yang mengadung unsur Nitrogen yang tinggi $(45-46 \%)$ dan mudah ditemukan di pasaran.

Unsur nitrogen merupakan unsur yang paling penting dan merupakan faktor pembatas untuk pertumbuhan plankton. Pemberian pupuk organik maupun anorganik seperti pupuk urea dan phospat mampu mempercepat pertumbuhan, pembentukan protein dan asam amino terutama plankton dan gejala kekurangan unsur hara nitrogen menyebabkan pertumbuhan lambat (Gusnilawati, 2010)

Budidaya perikanan tidak terlepas dari pentingnya zooplankton sebagai pakan alami untuk biota yang dibudidaya. Zooplankton yang dibudidayakan oleh petani maupun balai beragam jenis, diantaranya rotifer yang biasa dibudidayakan karena memiliki kandungan nutrisi yang tinggi dibandingkan dengan zooplankton lain. Dalam penelitian ini sebagai nutrisi tambahan rotifera menggunakan pupuk urea karena harganya yang ekonomis serta mudah di dapatkan khususnya di wilayah NTB ini.

\section{Metode}

\section{Waktu dan Tempat}

Penelitian ini akan dilaksanakan pada tanggal 21 Pebruari 2019 sampai selesai di Laboratorium Basah, Program Studi Budidaya Perairan Fakultas Pertanian Universitas Mataram.

\section{Alat-alat Penelitian}

Alat dan bahan yang digunakan pada penelitian ini adalah toples plastik 2,5 liter, aerator, lampu neon 36 watt, pipet tetes, mikroskop, handcounter, Sedwick rafter counting, $\mathrm{pH}$ meter, thermometer, timbangan digital, refraktometer, panci, lux meter, kompor, kertas label, alat tulis, kamera.

\section{Bahan-bahan Penelitian}

Adapun bahan yang digunakan yaitu, air laut, air tawar, pupuk Urea, pupuk KW21 dan bibit Rotifer.

\section{Metode Penelitian}

Penelitian menggunakan metode eksperimen terdiri dari 4 perlakuan yang diulang masing-masing 3 kali ulangan dimana Perlakuan1: KW21 $1 \mathrm{ml} / \mathrm{L}$ ( kontrol), Perlakuan 2 : Urea $50 \mathrm{mg} / \mathrm{L}$, Perlakuan 3 : Urea $100 \mathrm{mg} / \mathrm{L}$ dan Perlakuan 4 : Urea 150 mg/L. Pupuk urea digerus atau dihaluskan dengan alat penggerus. Kemudian dihaluskan dengan konsentrasi $10 \mathrm{~g}$ pupuk dengan $100 \mathrm{ml}$ air tawar yang dimasak kemudian dinginkan.

Bibit yang digunakan dalam penelitian ini berasal dari Balai Budidaya Laut (BBL) Lombok sebanyak 1.180.000 
ind/2000 ml. Bibit Brachionus plicatilis ini sebelumya dihitung terlebih dahulu kepadatannya untuk mengetahui padat tebar yang kita inginkan. Perhitungan jumlah inokulasi (kultur) menggunakan rumus sebagai berikut: $\mathrm{N}=\mathrm{ind} / \mathrm{ml}$. Keterangan : $\mathrm{N}=$ jumlah Brachionus plicatilis yang dihitung dalam $1 \mathrm{ml}$ pada SCR. Pemeliharaan Brachionus plicatilis, dilakukan selama 9 hari atau 216 jam dan pengamatan pertumbuhan rotiter setiap 24 jam.

Parameter kualitas air yang dilakukan yaitu suhu, $\mathrm{pH}$, salinitas, DO, nitrat dan nitrit. Pengukuran parameter pemiliharaan Brachiounus plicatilis, dilakukan pada awal dan akhir penelitian. Suhu diukur dengan menggunakan thermometer, $\mathrm{pH}$ diukur menggunakan $\mathrm{pH}$ meter, salinitas diukur dengan refraktometer, DO di ukur menggunakan DO meter dan nitrat-nitrit diukur menggunakan spektrofotometer. Parameter yang diuji dalam penelitian ini terdiri atas parameter utama dan parameter pendukung. Parameter utama meliputi laju pertumbuhan populasi (relatif, spesifik dan waktu penggandaan diri). Parameter pendukung meliputi kualitas air (suhu, salinitas, $\mathrm{pH}, \mathrm{DO}$ dan nitrat-nitrit).

\section{Laju pertumbuhan Populasi $K=\operatorname{Ln} \mathrm{N} t-\operatorname{Ln~NO} / t$}

Keterangan: $\mathrm{K}=$ laju pertumbuhan jumlah populasi Brachionus plicatilisi $\mathrm{nd} / \mathrm{ml}, \mathrm{Nt}=$ jumlah populasi Brachionus plicatili $s$ setelah hari tebar, No $=$ jumlah populasi awal Brachionus plicatilis, $\mathrm{t}=$ waktu pengamatan

\section{Laju Pertumbuhan Relatif

$$
\mathrm{RGR}=((N t-N O) / N O) \times 100 \%
$$

Keterangan : $\mathrm{RGR}=$ relative growth rate $(\%)$, N0 dan $\mathrm{Nt}=$ Kepadatan pupolasi (ind/mL) pada awal dan akhir periode pengamatan.

\section{Laju Pertumbuhan Spesifik}

$$
\mathrm{SGR}=((\log N t / \log N O) / t-t O
$$

Keterangan : $\mathrm{SGR}=$ Spesific growth rate (\% per jam), NO dan $N t=$ Kepadatan pupolasi (ind/mL) pada awal dan akhir periode pengamatan, $\mathrm{t}=$ lama periode pengamatan (jam)

\section{Waktu Penggandaan Diri (Double Time)$$
\mathrm{DT}=\log (2) x \Delta t /(\log N t-\log N O)
$$

Keterangan : DT $=$ Double time $(\mathrm{jam}), \mathrm{NO}$ dan $N t=$ Kepadatan pupolasi (ind $/ \mathrm{mL}$ ) pada awal dan akhir periode pengamatan, $\Delta \mathrm{t}=$ Lama waktu dalam satu waktu periode pengamatan (jam).

Analisis data yang digunakan dalam penelitian ini yaitu Analysis of variance (Anova) signifikasi 5\% $(0,05)$. Apabila terdapat pengaruh yang berbeda nyata, maka dilakukan Uji lanjut dengan uji Tukey.

\section{Hasil \\ Pertumbuhan Brachionus plicatilis}

Berdasarkan penelitian yang telah dilakukan selama 9 hari, diperoleh data rata-rata mengenai Laju Pertumbuhan Populasi, Pertumbuhan relatif, Pertumbuhan Spesifik dan Waktu Penggandaan Diri Brachionus plicatilis. (tabel 4)

Tabel 1. Laju Pertumbuhan Populasi dan Waktu penggandaan diri Brachionus plicatilis (rata-rata \pm standar deviasi )

\begin{tabular}{lll}
\hline Perlakuan & $1 \mathrm{ml} \mathrm{kw} 21$ (kontrol) & Urea 50 \\
& & \\
\hline Pertumbuhan Populasi & $2.88 \pm 0.11^{\mathrm{a}}$ & $3.34 \pm 0.0$ \\
Pertumbuhan relative & $17.00 \pm 2.00^{\mathrm{a}}$ & $27.33 \pm 0$ \\
Pertumbuhan spesifik & $1.24 \pm 0.04^{\mathrm{a}}$ & $1.44 \pm 0.0$ \\
& & \\
Waktu penggandaan diri & $1.97 \pm 0.07^{\mathrm{c}}$ & $1.67 \pm 0.0$ \\
\hline Keterangan : & &
\end{tabular}


- Huruf yang berbeda menunjukan ada pengaruh yang berbeda nyata terhadap setiap perlakuan.

Hasil pengamatan laju pertumbuhan populasi Brachionus plicatlis menunjukkan bahwa konsentrasi pupuk Urea yang diuji memberikan pola pertumbuhan populasi yang berbeda. Pada (Gambar 1).

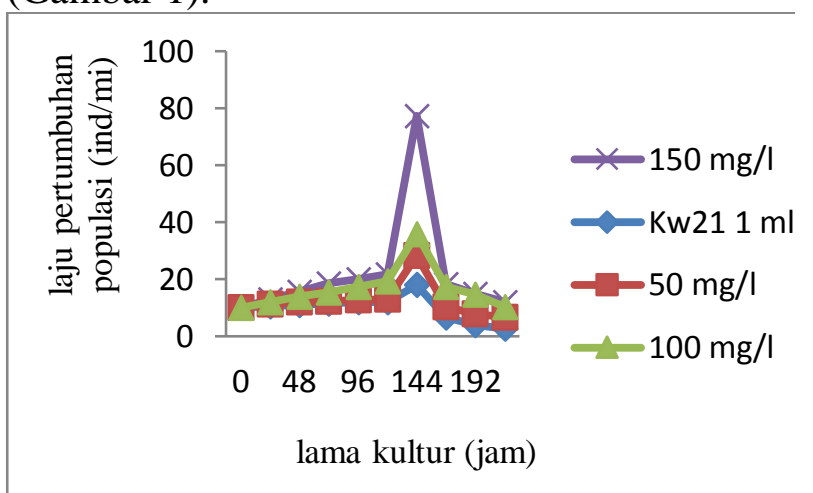

Gambar 1. Laju pertumbuhan populasi (ind $/ \mathrm{mL}$ ) pada masing masing kosentrasi (P1) KW21 $\mathrm{mL}$ (kontrol), (P2) urea 50mg/L, (P3) urea $100 \mathrm{mg} / \mathrm{L}$, (P4) urea 150mg/L.

Hasil pengamatan laju pertumbuhan Brachionus plicatilis di atas menunjukkan bahwa pada perlakuan kosentrasi $50 \mathrm{mg} / \mathrm{L}$, $100 \mathrm{mg} / \mathrm{L}, 150 \mathrm{mg} / \mathrm{L}$ dan KW21 (kontrol) terlihat Pertumbuhan Brachionus plicatilis dari hari ke 0 sampai hari ke 3 berlangsung lambat dimana menurut Hariyati (2008), pertumbuhan zooplankton pada awal pemeliharaan mengalami pertumbuhan yang lambat yang di sebut dengan fase lag.

Fase lag atau fase adaptasi merupakan fase dimana lambatnya pertumbuhanBrachionus plicatilis pada awal pemeliharaan karena terjadi proses penyesuaian diri terhadap perubahan kondisi lingkungan media hidup awal ke media yang baru. Kondisi ini dinamakan fase lag (fase lambat) yaitu fase pertumbuhan awal dimana penambahan kelimpahan individu yang terjadi jumlahnya sedikit (Isnansetyo dan Kurniastuty1995).

Selanjutnya hari ke 4 sampai hari ke 5 mengalami pertumbuhan yang cepat hingga mencapai kepadatan puncak hari ke 6 kemudian hari ke 7 sampai hari ke 8 mengalami penurunan sampai hari ke 9 mengalami kematian. Di peroleh bahwa laju pertumbuhan populasi Brachionus plicatilis tertinggi pada hari ke 6 setelah itu terjadi fase penurunan.

Dalam penelitian ini, kosentrasi urea $150 \mathrm{mg} / \mathrm{L}$ menghasilkan laju pertumbuhan tertinggi yaitu $4.34 \mathrm{ind} / \mathrm{ml}$, urutan tertinggi berikutnya diperlihatkan oleh kosentrasi urea $100 \mathrm{mg} / \mathrm{L}$ yaitu $3.58 \mathrm{ind} / \mathrm{ml}$, kosentrasi urea $50 \mathrm{mg} / \mathrm{L}$ yaitu $3.34 \mathrm{ind} / \mathrm{ml}$, dan yang terendah laju pertumbuhan populasi terdapat pada perlakuan dengan kosentrasi KW21 (kontrol) yaitu 2.88 ind $/ \mathrm{ml}$. Dimana pada fase ini terjadi fase logaritmik atau eksponensial terjadi hari sampai hari ke 6 dimana jumlah pertambahan individu sangat banyak, tingginya kepadatan populasi ini di sebabkan karna pada media kultur kandungan nutrient cukup banyak yang dapat dimanfaatkan untuk pertumbuhan sehingga terjadi pertambahan jumlah individu secara cepat. Hal ini sesuai dengan pernyataan Priyambodo (2001), bahwa dalam mengkultur Brachionus plicatilis ketersediaan pakan sangat menentukan terhadap laju pertumbuhan populasinya, apabila kekurang nutrien dalam bahan media dapat menyebabkan terjadinya penurunan laju pertumbuhannya.

Fase stasioner dicapai saat laju reproduksi sama dengan laju kematian, dengan demikian penambahan dan pengurangan jumlah populasi relative sama atau seimbang sehingga kepadatan populasi tetap. Fase ini terjadi pada hari ke 7 dan hari ke 8 semua perlakuan. Penurunan pada fase tersebut disebabkan karena keterbatasan nutrien sehingga menghambat proses metabolisme Brachionus plicatilis. Putri (2013), menyatakan penurunan kecepatan pertumbuhan pada fase stasioner disebabkan keterbatasan nutrien dan terbentuknya senyawa metabolit sekunder, hasil metabolisme yang terakumulasi 
dalam media kultur dapat menghambat proses metabolisme.

Fase kematian dimana laju kematian lebih tinggi dibandingkan laju reproduksinya. Menurut Rusyani (2001), menyatakan bahwa terjadinya penurunan pertumbuhan setelah pertumbuhan puncak karna media kultur yang terbatas, baik kandungan nutrien maupun volume media kultur. Penelitian ini menunjukan bahwa semakin tinggi kosentrasi pupuk urea, maka semakin tinggi pula pertumbuhan populasi individu Brachionus plicatilis.

\section{Laju Pertumbuhan Relatif ( RGR )}

Pertumbuhan relatif populasi Brachionus plicatilis diperoleh dari presentase selisih antara kepadatan awal dan kepadatan puncak kemudian dibandingkan dengan kepadatan awal. Konsentrasi pupuk Urea $150 \mathrm{mg} / \mathrm{L}$ menghasilkan pertumbuhan relatif tertinggi yaitu $76.33 \%$, urutan berikutnya diperlihatkan oleh Urea $100 \mathrm{mg} / \mathrm{L}$ yaitu 35 $\%$, Urea $50 \mathrm{mg} / \mathrm{L}$ yaitu $27.33 \%$ dan terendah KW2117 \%. Penelitian ini menunjukan bahwa semakin tinggi konsentrasi pupuk urea maka pertumbuhan semakin akan meningkat namun setelah mencapai titik optimum memperlihatkan pertumbuhan relatif menurun.

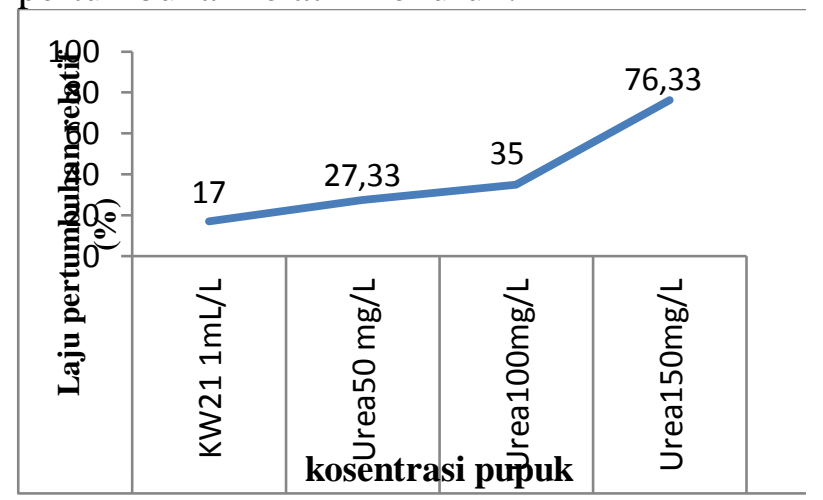

Gambar 2. Laju pertumbuhan relatif (\%) pada masing masing kosentrasi(p1) KW21 mL (kontrol), (p2) urea 50 $\mathrm{mg} / \mathrm{L}$, (p3) urea $100 \mathrm{mg} / \mathrm{L}$, (p4) urea $150 \mathrm{mg} / \mathrm{L}$.

\section{Laju Pertumbuhan Spesifik dan Waktu Penggandaan Diri Brachionus plicatilis}

$\begin{array}{crr}\text { Laju } & \text { perumbuhan } & \text { spesifik } \\ \text { merupakan } & \text { parameter } & \text { yang }\end{array}$ menggambarkan kecepatan pertambahan populasi Brachionus plicatilisper satuan waktu. Setelah masa adaptasi berakhir terjadi pertumbuhan yang tercepat pada fase eksponensial. Pada (Gambar 7), meununjukkan waktu penggandaan diri (double time)Brachiounus plicatilis tersingkat ditunjukkan pada perlakuandengan konsentrasi $150 \mathrm{mg} / \mathrm{L}$ dengan nilai rata-rata 1.31 jam.

Pada perlakuan ini pula pertumbuhan populasi Brachionus plicatilis mengalami peningkatan dengan laju pertumbuhan spesifik sebesar $1.88 \%$ per jam (Gambar6). Waktu penggandaan diri paling lama ditunjukkan oleh perlakuan kontrol KW21 dengan rata-rata 1.97 jam (Gambar6) dan pada perlakuan ini pula laju pertumbuhan spesifik sebesar $1.24 \%$ per jam (Gambar 7). Hal ini sesuai pernyataan Afriza et, al.(2015), waktu regenerasi yang lebih rendah berarti pertumbuhan jumlah populasi lebih cepat karena waktu yang diperlukan untuk memperbanyak individu lebih singkat sehingga untuk mencapai kepadatan maksimum lebih cepat.

Hasil analisis parameter kualitas air (tabel 5) menunjukkan bahwa salinitas media air selama penelitian relatif pada tingkat 30-31 ppt, Tingkat keasaman air tetap berada dalam keadaan relatif 7,5-8,0, DO 5,0-6,0 mg/L , suhu 27-29 ${ }^{\circ} \mathrm{C}$. Media air selama penelitian dari awal sampai akhir selalu dalam keadaan relatif optimum untuk pertumbuhan Brachionus plicatilis. Dapat di lihat pada (tabel 5) kandungan nitrat-nitrit yang terdapat di semua perlakuan kosentrasi urea berada dalam keadaan relatif dengan nilai sebesar 1.18$0.051 \mathrm{mg} / \mathrm{L}$ sehingga parameter kualitas air pada media kultur tersebut berada pada rentang optimum untukpertumbuhan Brachionus plicatilis sedangkan kandungan nitrat-nitrit di perlakuan KW21 (kontrol), dengan nilai sebesar 18.82-0.095 mg/L sehingga menyebabkan Branchionus plicatilis memanfaatkkan unsur hara dalam 
media tersebut secara terbatas dikarenakan kadar nitrat-nitrit pada media KW21 (kontrol) sudah melewati batas optimum.

Menurut Borowitzka (1998) dalam Afriza et, al. (2015), menjelaskan bahwa nitrogen dapat mempengaruhi pertumbuhan Brachionus plicatilis, pembentukan protein dan asam amino. Perbedaan pertumbuhan harian setiap perlakuan tersebut disebabkan oleh kemampuan individu dalam menyerap unsur hara yang terdapat pada media kultur.Hal ini juga sejalandengan pernyataan Afriza et, al. (2015), terkadang kosentrasi bahan yang terlalu tinggi membuat bahan sulit untuk diserap oleh individu.Sehingga di asumsikan bahwa hasil laju pertumbuhan populasi, laju pertumbuhan relatif, laju pertumbuhan spesifik dan waktu penggandaan diri Brachionus plicatilis yang didapat pada penelitian ini dipengaruhi oleh unsur nitrogen yang terkandung dalam pupuk urea maupun pupuk KW21 dengan konsentrasi yang berbeda.

\section{Kesimpulan}

kesimpulan dari penelitian ini adalah sebagai berikut :

1. Pemberian kosentrasi pupuk urea memberikan pengaruh terhadap laju pertumbuhan populasi, pertumbuhan relatif, pertumbuhan spesifik dan Waktu penggandaan diri Brachionus plicatilis.

2. Kosentrasi urea $150 \mathrm{mg} / \mathrm{L}$ merupakan kosentrasi terbaik untuk pertumbuhan Brachionus plicatilis.

\section{Daftar pustaka}

Afriza, Z., G. Diansyah, dan Anna, I. S. P. 2015. Pengaruh Pemberian Pupuk Urea (CH4N2O) Dengan Dosis Berbeda Terhadap Kepadatan Sel Dan Laju Pertumbuhan Porphyridium Sp. Pada Kultur Plankton Skala Laboratorium. Jurnal Maspari Journal Juli 2015 Vol 7 (2) : 33-40
Chumaidis. Ilyas, Yunus, Sachlan, R.Utami, A.Priyadi,Pt Imanto, S.T. Hartati, P.Bastian, Z.Jangkuru, R.Arifudin 1992. Petunjuk teknis budidaya pakan alami ikan dan udang. Pusat Penelitian dan Pengembangan Perikanan, Jakarta : $84 \mathrm{pp}$.

Dini,W. W. 2012. Kombinasi Pupuk Urea Dan Perasan Eucheuma Sp. TerhadapPopulasi Nannochloropsis oculata. Skripsi. Fakultas Perikanan Dan Kelautan Universitas Airlangga. Surabaya.

Djarijah, A. B. 1995. Pakan ikan alami. Cetakan I. Yogyakarta: penerbit kanisius. Hlm.12-13;35-55

Edhy,W. A., J. Pribadi , dan Kuniawan . 2003. Plankton di lingkungan PT. Central Pertiwi Bahari Suatu Pendekatan Biologi dan Managemen dalamBudidaya Udang Laboratorium Central Departement Aquaculture DivisionPT. Central Pertiwi Bahari.

Fajryani, D. 2006. Studi pertumbuhan mikro alga laut chaetoceros pada beberapa kandungan $\mathrm{CO}_{2}$ dan $\mathrm{NaHCO}_{3}$ yang berbeda. Fakultas perikanan dan ilmu kelautan. Institute pertanian Bogor.

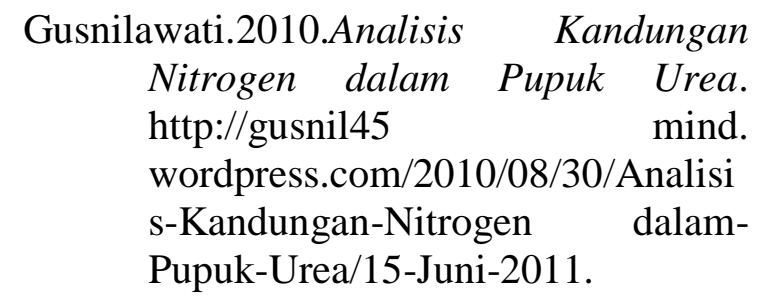

Haryati R. 2008 pertumbuhan dan biomassa spirulina sp. Dalam skala laboraturium. Ekologi dan biosistematik. Jurnal jurusan biologi FMIPA.undipBioma ISSN:1410-8801 vol.10, no. 1 hal.19-22 
Irwanti,Defira N.C, Dewiyanti I. 2016 Pengaruh pemberian pakan yang berbeda terhadap laju pertumbuhan rotifera (Brachionus plicatilis).Program Studi Budidaya Perairan. Fakultas Kelautan dan Perikanan. Universitas Syiah Kuala Darussalam, Banda Aceh.

Isnansetyo,dan Kurniastuty.1995.Teknik kultur phytoplankton dan zooplankton : pakan alamiikan untuk pembenihan organisme laut. Yogyakarta: penerbit kanisius.hlm14-15

Mukhlis, A. 2017. Penuntun Praktikum Teknologi Budidaya Pakan Alami.Program Studi Budidaya Perairan. Universitas Mataram.

Mujiman, A. 1998. Makanan ikan. Jakarta: penerbit PT. Penebar swadaya: hlm 14-17, 49-51

Mawaddah, A. Roto. A, Suratman. 2016. Pengaruh Penambahan Urea Terhadap

Peningkatan Pencemaran Nitrit dan Nitrat Dalam Tanah. Jurnal. Manusia dan Lingkungan. Volume $3(3): 360-364$.

Priyambodo, 2011. Budiaya pakan alami untuk ikan. Jakarta: penerbit PT. Penebar Swadaya.hlm.28

Riyono, S. H. 2007. Beberapa Sifat Umum Dari Klorofil Fitoplankton. Jurnal Oseana, Volume XXXII, Nomor 1 : $22-31$.
Redjeki S., 1999. Budidaya Rotifera ( Brachionus plicatilis).Oseana, Volume XXIV, Nomor 2,1999: 27-43

Riesya, D. A., dan T. Nurhidayati. 2013. Pengaruh Kombinasi Konsentrasi Media

Ekstrak Tauge (MET) dengan Pupuk Urea Terhadap Kadar Protein Rotifer. Jurnal. Sains dan Seni Pomits, Vol 2 (2) : 2337 3520.

Suharja danSutorno. 2009. Biomassa, kandungan klorofil dan nitrogen daun dua varietas cabai (Capsicum annum) pada berbagai perlakuan pemupukan. Jurnal 10 hal.

Sururi, A. 2014. Budidaya Ikan Hias Clown. Program Pengembangan Sumberdaya Perikanan Balai Perikanan Budidaya Laut : Ambon

Safrizal, erlita, humairani R, 2013. Peningkatan laju pertumbuhan populasi rotifera (brachiounus plicatilis) sesudah diberikan penambahan makanan pada media perlakuan.Alumni Program Studi Budidaya Perairan Fakultas Pertanian Universitas Almuslim.Vol.13 no.2

Sumarlinah. 2000. Hubungan Komunitas Fitoplankton Unsur Hara Nitrogen dan Fosfor di Danau Sunter Selatan. Jakarta Utara. Skripsi. Program StudiManajemen Sumber Daya Perairan. Fakultas Perikanan, Institut PertanianBogor. 62 hal. 